\title{
A survey of Wolbachia, Spiroplasma and other bacteria in parthenogenetic and non-parthenogenetic phasmid (Phasmatodea) species
}

\author{
Mar PÉREZ-RUIZ ${ }^{1}$, Paloma MARTÍNEZ-RODRÍGUEZ ${ }^{1, *}$, Jesús HERRANZ² and José L. BELLA ${ }^{1}$ \\ ${ }^{1}$ Departamento de Biología (Genética), Facultad de Ciencias, Universidad Autónoma de Madrid, C/ Darwin 2, E28049 Madrid, \\ Spain; e-mails: mariamar.perezr@estudiante.uam.es; paloma.martinez@uam.es; bella@uam.es \\ ${ }_{2}^{2}$ Departamento de Ecología, Facultad de Ciencias, Universidad Autónoma de Madrid, C/ Darwin 2, E28049 Madrid, Spain; \\ e-mail: jesus.herranz@uam.es
}

Key words. Wolbachia, Spiroplasma, bacterial endosymbionts, parthenogenesis, phasmids, phasmid microbiota

\begin{abstract}
The ecological and genetic mechanisms that determine Phasmatodea reproductive biology are poorly understood. The order includes standard sexual species, but also many others that display distinct types of parthenogenesis (tychoparthenogenesis, automixis, apomixis, etc.), or both systems facultatively. In a preliminary survey, we analysed Wolbachia and Spiroplasma infection in 244 individuals from 28 species and 24 genera of stick insects by bacterial $16 S r R N A$ gene amplification. Our main aim was to determine whether some of the bacterial endosymbionts involved in distinct reproductive alterations in other arthropods, including parthenogenesis and male killing, are present in phasmids. We found no Wolbachia infection in any of the phasmid species analysed, but confirmed the presence of Spiroplasma in some sexual, mixed and asexual species. Phylogenetic analysis identified these bacterial strains as belonging to the Ixodetis clade. Other bacteria genera were also detected. The possible role of these bacteria in Phasmatodea biology is discussed.
\end{abstract}

\section{INTRODUCTION}

Parthenogenesis is a very common phenomenon in most animal groups, a reproductive mode that limits genetic recombination. Parthenogenetic females can, in principle, transfer all their genes to their offspring, while a bisexual female transmits only half of them because her chromosome number is reduced during meiosis. This can be interpreted as meaning that the representation of parthenogenetic female genes will double in the next generation, although this is controversial (Suomalainen et al., 1987). However, this could explain why the bacterial endosymbiont Wolbachia manipulates host reproduction in some cases (Werren et al., 2008). Given its almost complete maternal transmission, inducing parthenogenesis, clearly helps its own transmission, accompanied by the "correct" host genes, i.e. those ensuring parthenogenesis.

According to different estimates, Wolbachia affects around $40 \%$ of arthropod species. These Alphaproteobacteria mainly parasitize the reproductive tissues (eggs and testes) of their hosts, whose reproduction can be altered through male killing, feminization, parthenogenesis and cytoplasmic incompatibility (Werren et al., 2008; Brucker \& Bordenstein, 2012; Zug \& Hammerstein, 2012). Wolbachia-induced parthenogenesis has been documented in mites, thrips and several members of the order Hymenoptera (Pannebakker et al., 2004; Werren et al., 2008; Kremer et al., 2009; Watanabe et al., 2013), although other bacterial genera, such as Rickettsia and Cardinium, also seem able to induce parthenogenesis in Hymenoptera (Rabeling \& Kronauer, 2013).
The order Phasmatodea has interesting biological and ecological characteristics. It comprises more than 2,500 species, some of which - the stick insects - bear a striking resemblance to branches or leaves. Parthenogenesis occurs in a number of phasmids (Bedford, 1978) and is particularly well documented in the genera Bacillus and Timema (Trewick et al., 2008; Schwander \& Crespi, 2009), as well as occurring in Sipyloidea, Carausius, Clitumnus and many other genera (Suomalainen et al., 1987; Lacadena, 1996) (Table 1). There have been no reports of parthenogenesis induced by bacteria in phasmids, but a survey of the literature suggests this may primarily be because this possibility has not been explored empirically.

On the other hand, Spiroplasma phylum (Firmicutes) is another bacterial endosymbiont that can be considered one of the most important taxa because of its wide host range. It appears mainly in insects, but is occasionally found in other invertebrates (Haselkorn, 2010). This bacterial genus has been detected among the gastric flora of many arthropod species. Its association with intestinal epithelial cells appears to produce no adverse effects, and the genus is therefore considered to be commensal. However, under other circumstances, members of the genus are described as pathogens. The transition to pathogenicity may be linked to the ability to cross the barrier of the insect gut (Haselkorn, 2010) to reach the haemolymph, ovaries, salivary glands or hypodermis (Regassa \& Gasparich, 2006). They have been characterised as pathogenic bacteria in shrimps, crabs and bees, in which they cause high levels of mortality (Haselkorn, 2010). In certain hosts infection

\footnotetext{
* Present address: BPI - Biologie des Populations Introduites, Institut Sophia Agrobiotech (INRA PACA), 400 route des Chappes, BP 167, 06903 Sophia Antipolis cedex, France.
} 
TABle 1. Species of the Phasmatodea order examined in this study. * Sex unknown (nymphs or juvenile individuals). Phasmid species and individuals analysed by PCR for the $16 S$ rDNA of Wolbachia sp., Spiroplasma sp. or eubacteria (number of infected individuals in brackets). Characterisation of the PCR products by sequencing and BLAST alignment. Source: samples kindly donated by J. HerranzBarrera (Madrid, Spain) and A. Sevilla-Esquinas (Madrid) (1), P. Ruíz-Mínguez (Madrid) (2), J. Rodríguez-García (Villagarcía de Arosa, Spain) (3), and A. Fernández-Ramos (Madrid) (4).

\begin{tabular}{|c|c|c|c|c|c|c|c|c|}
\hline Species & $\begin{array}{c}\text { Individuals } \\
\text { analysed }\end{array}$ & Sex & Reproduction & $\begin{array}{l}\text { Wolbachia } \\
\text { sp. }\end{array}$ & $\begin{array}{l}\text { Spiro- } \\
\text { plasma sp. }\end{array}$ & Eubacteria & Origin & Source \\
\hline Achrioptera fallax & 3 & $3 *$ & Sexual & 0 & 0 & - & Madagascar & 2 \\
\hline Diapherodes gigantea & 2 & $\begin{array}{l}1 * \\
1{ }^{\lambda}\end{array}$ & Sexual & 0 & 1 & $\begin{array}{c}\text { Serratia } \\
\text { marcescens (1) }\end{array}$ & $\begin{array}{l}\text { Antilles- } \\
\text { Grenada }\end{array}$ & 2 \\
\hline Diapherodes venustula & 3 & $\begin{array}{ll}1 & \text { क } \\
2 \hat{O}\end{array}$ & Sexual & 0 & 0 & - & Cuba & 2,3 \\
\hline Entoria nuda & 12 & 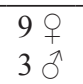 & $\begin{array}{l}\text { Parthenogenetic/ } \\
\text { Sexual }\end{array}$ & 0 & 3 & $\begin{array}{l}\text { Lactococcus } \\
\text { lactis (1) }\end{array}$ & Japan & 1,2 \\
\hline Epidares nolimetangere & 3 & $3 \delta^{\lambda}$ & Sexual & 0 & 0 & - & Borneo & 2 \\
\hline Eurycantha calcarata & 4 & $\begin{array}{ll}1 & 9 \\
1 & 1 \\
2 *\end{array}$ & $\begin{array}{l}\text { Parthenogenetic / } \\
\text { Sexual }\end{array}$ & 0 & 0 & $\begin{array}{c}\text { Lactococcus } \mathrm{sp} .(1) \\
\text { Enterobacter } \\
\text { ludwigii (1) }\end{array}$ & New Guinea & 2 \\
\hline Extatosoma tiaratum & 9 & 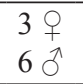 & $\begin{array}{l}\text { Parthenogenetic } \\
\text { / Sexual }\end{array}$ & 0 & 0 & - & Australia & 4 \\
\hline Hypocyrtus scythrus & 8 & $8^{*}$ & Sexual & 0 & 0 & - & - & 4 \\
\hline Leptynia montana & 19 & $\begin{array}{c}11 \text { o } \\
8 \hat{O}\end{array}$ & Sexual & 0 & 1 & $\begin{array}{l}\text { Methylobacterium } \\
\text { thiocyanatum }(2) \\
\text { Nevskia ramosa }(1)\end{array}$ & Spain & 1 \\
\hline $\begin{array}{l}\text { Lonchoides sp. } \mathrm{n} . \\
\text { (Negros Is.) }\end{array}$ & 1 & $10^{\pi}$ & Sexual & 0 & 0 & - & Philippines & 1 \\
\hline $\begin{array}{l}\text { Medauroidea } \\
\text { extradentata }\end{array}$ & 23 & $\begin{array}{c}17 \text { ㅇ } \\
5 \text { o } \\
1^{*}\end{array}$ & $\begin{array}{l}\text { Facultatively partheno- } \\
\text { genetic / Sexual }\end{array}$ & 0 & 0 & $\begin{array}{c}\text { Lactococcus lactis (1) } \\
\text { Cupriavidus sp. (1) }\end{array}$ & Vietnam & 1 \\
\hline Mnesilochus latifemur & 7 & $\begin{array}{l}4+9 \\
3 \hat{0}\end{array}$ & Sexual & 0 & 0 & - & Malaysia & 3 \\
\hline Neohirasea maerens & 15 & $\begin{array}{c}14+9 \\
10\end{array}$ & $\begin{array}{l}\text { Facultatively partheno- } \\
\text { genetic / Sexual }\end{array}$ & 0 & 1 & $\begin{array}{l}\text { Rahnella aquatilis (1) } \\
\text { Serratia } \mathrm{sp.} \text { (1) }\end{array}$ & Vietnam & 1 \\
\hline $\begin{array}{l}\text { Parapachymorpha } \\
\text { zomproi }\end{array}$ & 1 & 1 ㅇ & $\begin{array}{c}\text { Parthenogenetic / } \\
\text { Sexual }\end{array}$ & 0 & 0 & - & Thailand & 3 \\
\hline Periphetes forcipatus & 4 & $4 *$ & Sexual & 0 & 0 & Brevibacterium sp. (1) & Indonesia & 2 \\
\hline Peruphasma schulteii & 18 & $\begin{array}{l}7+ \\
11 * \\
\end{array}$ & Sexual & 0 & 0 & - & Peru & $1,2,4$ \\
\hline $\begin{array}{l}\text { Phaenopharos } \\
\text { khaoyaiensis }\end{array}$ & 17 & 17 우 & Parthenogenetic & 0 & 0 & $\begin{array}{c}\text { Cupriavidus } \\
\text { metallidurans (1) }\end{array}$ & Thailand & 1 \\
\hline Pharnacia ponderosa & 2 & $2 *$ & Sexual & 0 & 0 & Serratia marcescens (1) & Philippines & 2 \\
\hline Phyllium giganteum & 4 & 49 & Parthenogenetic & 0 & 0 & - & Malaysia & 2 \\
\hline Phyllium jacobsoni & 1 & 10 & Sexual & 0 & 0 & - & Java & 2 \\
\hline Phyllium philippinium & 12 & 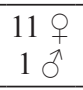 & $\begin{array}{c}\text { Parthenogenetic / } \\
\text { Sexual } \\
\end{array}$ & 0 & 0 & - & Philippines & 2 \\
\hline Phyllium westwoodii & 16 & $16 *$ & $\begin{array}{l}\text { Parthenogenetic / } \\
\text { Sexual }\end{array}$ & 0 & 0 & $\begin{array}{c}\text { Serratia sp. (2) } \\
\text { Cupriavidus sp. (1) }\end{array}$ & Thailand & 2 \\
\hline Ramulus artemis & 19 & 19 우 & Parthenogenetic & 0 & 11 & - & Vietnam & 1,2 \\
\hline Sipyloidea sipylus & 1 & 19 & Parthenogenetic & 0 & 1 & - & Madagascar & 1 \\
\hline Sungaya inexpectata & 12 & $\begin{array}{l}8 q \\
40\end{array}$ & $\begin{array}{l}\text { Parthenogenetic / } \\
\text { Sexual }\end{array}$ & 0 & 1 & Enterobacter sp. (1) & Philippines & 1,2 \\
\hline Tirachoidea biceps & 3 & $\begin{array}{l}1 \% \\
2 \stackrel{+}{\lambda}\end{array}$ & Sexual & 0 & 0 & $\begin{array}{c}\text { Serratia } \\
\text { liquefaciens (1) }\end{array}$ & Java & 2 \\
\hline Trachyareaton carmelae & 12 & $\begin{array}{c}2+ \\
10 *\end{array}$ & Sexual & 0 & 0 & - & Philippines & $1,2,4$ \\
\hline $\begin{array}{l}\text { Trachyareaton sp. n. } \\
\text { (Aurora Prov., Luzon) }\end{array}$ & 13 & $13 *$ & - & 0 & 0 & - & Philippines & 2 \\
\hline Total & 244 & 173 & & 0 & 19 & 19 & & \\
\hline
\end{tabular}


with these bacteria may impair reproduction: the bacterium is transmitted maternally, inducing the selective elimination of male progeny. This phenotype is called male killing (Regassa \& Gasparich, 2006). The most widely studied example is $S$. poulsonii, which was isolated from neotropical species of Drosophila willistoni (Sturtevant) (Williamson et al., 1999), in which, in the most extreme case, all the male offspring of infected females are eliminated. Other instances of male killing have been detected in strains of Spiroplasma that infect D. melanogaster Meigen (Montenegro et al., 2005), Danaus chrysippus (L.) (Lepidoptera: Danaidae) (Jiggins et al., 2000) and Adalia bipunctata (L.) (Coleoptera: Coccinelidae) (Hurst et al., 1999a), among others. In cases without male killing, males and females can both be infected with no obvious change in the phenotype (Haselkorn, 2010). In natural populations of Drosophila, an $85 \%$ infection rate of non-male-killing Spiroplas$m a$ has been noted (Watts et al., 2009).

In phasmids, Spiroplasma has been described in two Argentinian populations of Agathemera spp., as well as in their parasitic mites of the genus Leptus (Leptidae) (DiBlasi et al., 2011), although their phenotypic effects have not been associated with male killing. In addition, this endosymbiont has been identified in the strictly parthenogenetic Ramulus artemis (Westwood) and in the sexual Pharnacia ponderosa Stål (Shelomi et al., 2013), with unknown phenotypic effects.

Wolbachia and Spiroplasma are inherited endosymbionts that can have various influences on their hosts, ranging from mutualistic to parasitic effects, potentially affecting their reproduction and evolution. Both bacteria are transmitted maternally from infected females to their offspring and are not incompatible with each other (Duron et al., 2008, Martinez-Rodriguez et al., 2013). Driving host reproduction leads to an increase in the number of infected females, even at the expense of males, improving the fitness of the bacterium and its transmission between individuals within the population (Haselkorn, 2010).

Stick insect species exhibit a wide range of reproductive mechanisms, some of which are characterised by the absence of males and are therefore compatible with the involvement of these bacteria or of others with similar ef- fects. We explored this possibility in a broad survey of species of phasmids using a polymerase chain reaction (PCR) / DNA sequencing approach.

\section{MATERIAL AND METHODS}

\section{Obtaining DNA and PCR characterisation}

We obtained data from 244 individuals representing 28 species and 24 genera of the order Phasmatodea. Insects were collected in 2012 and 2013 from distinct captive populations of different geographic origin, all of them naturalised in Spain (Table 1). These individuals were kindly donated for this study, as recognised in Table 1 , and preserved in absolute ethanol at $-20^{\circ} \mathrm{C}$ until analysed.

Genomic DNA was obtained in different ways, depending on the size of the organism: (1) large individuals - from an abdominal fragment containing the gonads; (2) medium-sized adults from the abdomen; and (3) small adults, nymphs and juveniles of reduced size - from the whole body (except for the head, in order to exclude eye pigments, which reduce the quality of the DNA), as detailed in Zabal-Aguirre et al. (2010) and Martinez-Rodriguez et al. (2013). DNA samples were standardised at a final concentration of $50 \mathrm{ng} / \mu \mathrm{l}$ using a NanoDrop 1000 Spectrophotometer (Thermo Scientific, Wilmington, USA).

Preliminary analyses were performed to check the quality of the DNA samples. This enabled us to confirm that these were not fragmented, allowing further microbial detection (see below): (i) for each sample, a $2 \%$ agarose electrophoretic gel with $2 \mu \mathrm{l}$ of sample was run at $70 \mathrm{~V}$, and (ii) a PCR of the cytochrome oxidase I (COI) mitochondrial gene, and $0.6 \mathrm{mM}$ of each primer (numbered as 1 in Table 2) were used in PCR reactions performed in a final volume of $50 \mu \mathrm{l}(1 \times$ buffer, $2.0 \mathrm{mM} \mathrm{MgCl}, 0.2 \mathrm{mM}$ dNTPs, $1.25 \mathrm{U} \mathrm{Taq}$ polymerase and $2.0 \mu \mathrm{l}(100 \mathrm{ng})$ of DNA). Reagents were supplied by BIOTAQ (Bioline Reagents Ltd, London, UK). A Techne TC-512 thermocycler was programmed to give an initial denaturation step at $94^{\circ} \mathrm{C}$ for $10 \mathrm{~min}$, followed by 36 cycles of denaturation at $94^{\circ} \mathrm{C}$ for $30 \mathrm{~s}$, an annealing step at $54^{\circ} \mathrm{C}$ for 45 $\mathrm{s}$, an elongation step at $72^{\circ} \mathrm{C}$ for $90 \mathrm{~s}$, and a single final elongation cycle at $70^{\circ} \mathrm{C}$ for $10 \mathrm{~min}$.

Wolbachia infection in these phasmids was checked by PCR detection of the $16 S$ rRNA sequence from this bacterium (Table 2 , primers $n^{\circ} 2$ ). When amplification was not detected by electrophoresis or the negative controls produced a band, the resulting products were re-amplified with the same primers to test for possible false-negatives due to low-level infection or contamination, respectively. Reactions were performed in a final volume of 50 $\mu 1$, containing $1 \times$ buffer, $2.0 \mathrm{mM} \mathrm{MgCl}, 0.2 \mathrm{mM}$ dNTPs, 0.6

TABLE 2. PCR primers used to amplify the cytochrome oxidase I (COI) mitochondrial gene (1) in order to check the quality of the DNAs examined, or to detect possible bacterial endosymbionts in the phasmid species studied: $16 \operatorname{SrDNA}(2)$ and $w s p$ (primers 3 ) from Wolbachia, $16 \mathrm{~S}$ rDNA from Spiroplasma (4) and from eubacteria (5).

\begin{tabular}{|c|c|c|c|c|}
\hline \multicolumn{2}{|c|}{ Primers } & \multirow{2}{*}{$\begin{array}{l}\text { Sequence }\left(5^{\prime}-3^{\prime}\right) \\
\text { TTGATTTTTTGGTCATCCAGAAGT }\end{array}$} & \multirow{3}{*}{$\frac{\text { Size }}{753 \mathrm{bp}}$} & \multirow{3}{*}{$\frac{\text { Reference }}{\text { Simon et al., } 1994}$} \\
\hline \multirow[b]{2}{*}{1} & C1-J-2195 & & & \\
\hline & TL2-N-3014 & TCCAATGCACTAATCTGCCATATTA & & \\
\hline \multirow{2}{*}{2} & 16S_F & TTGTAGCTTGCTATGGTATAACT & \multirow{2}{*}{$1400 \mathrm{bp}$} & \multirow{2}{*}{ Zabal-Aguirre et al., 2010} \\
\hline & $16 \mathrm{~S} \_\mathrm{R}$ & ACTGCTACCTTGTTACGACTT & & \\
\hline \multirow{2}{*}{3} & Wsp_F1 & GTCCAATARSTGATGARGAAAC & \multirow{2}{*}{$603 \mathrm{bp}$} & \multirow{2}{*}{ Baldo et al., 2005, 2006} \\
\hline & Wsp_R1 & CYGCACCAAYAGYRCTRTAAA & & \\
\hline \multirow{2}{*}{4} & MGSO & TGCACCATCTGTCACTCTGTTAACCTC & \multirow{2}{*}{$500 \mathrm{bp}$} & van Kuppeveld et al., 1992 \\
\hline & HA-IN-1 & GCTCAACCCCTAACCGCC & & Hurst et al., 1999b \\
\hline \multirow{2}{*}{5} & $9.27 \mathrm{~F}$ & GAGTTTG(AC)TCCTGGCTCAG & \multirow{2}{*}{1492 bp } & \multirow{2}{*}{ Lane, 1991} \\
\hline & $1492.1512 \mathrm{R}$ & ACGG(CT)TACCTTGTTACGACTT & & \\
\hline
\end{tabular}


$\mathrm{mM}$ of each primer, 1.25 U of BIOTAQ polymerase (Bioline), and $2 \mu \mathrm{l}$ of standardized DNA template solution from each individual insect analysed (100 ng). A Techne TC-512 thermocycler was programmed for $94^{\circ} \mathrm{C}$ for $2 \mathrm{~min}$, followed by 37 cycles of $94^{\circ} \mathrm{C}$ for $30 \mathrm{~s}, 58^{\circ} \mathrm{C}$ for $1 \mathrm{~min}, 72^{\circ} \mathrm{C}$ for $90 \mathrm{~s}$, and a single final elongation cycle at $70^{\circ} \mathrm{C}$ for $10 \mathrm{~min}$ (see Zabal-Aguirre et al., 2010).

To verify our results, a further Wolbachia detection system was developed: PCR of the wsp gene of Wolbachia (Table 2, primers $\mathrm{n}^{\mathrm{o}} 3$ ) was performed in a final volume of $40 \mu \mathrm{l}$ containing $1 \times$ buffer, $1.5 \mathrm{mM} \mathrm{MgCl}, 0.2 \mathrm{mM}$ dNTPs, $1 \mu \mathrm{M}$ of each primer, $0.5 \mathrm{U}$ of BIOTAQ polymerase (Bioline), and $2 \mu 1$ of standardised DNA template solution from each individual (100 ng). Techne TC-512 thermocycler conditions were here $94^{\circ} \mathrm{C}$ for $2 \mathrm{~min}$, followed by 37 cycles of $94^{\circ} \mathrm{C}$ for $30 \mathrm{~s}, 58^{\circ} \mathrm{C}$ for $1 \mathrm{~min}$ and $72^{\circ} \mathrm{C}$ for $90 \mathrm{~s}$, followed by a final elongation cycle at $72^{\circ} \mathrm{C}$ for $10 \mathrm{~min}$.

Spiroplasma infection was tested for the presence of the $16 \mathrm{~S}$ $\mathrm{r} R N A$ gene by PCR using specific primers as shown in Table 2 (primers $\mathrm{n}^{\circ} 4$ ). The possible presence of other bacteria in the individual insects as studied here was also checked by PCR of their $16 S \mathrm{r} R N A$ sequences using universal primers for eubacteria (Table 2, primers $\mathrm{n}^{\circ} 5$ ). For these amplifications, reactions were conducted in a final volume of $50 \mu 1$ containing the appropriate 1 $\times$ buffer, $2.0 \mathrm{mM} \mathrm{MgCl}, 0.2 \mathrm{mM}$ dNTPs, $0.6 \mathrm{mM}$ of each primer, $1.25 \mathrm{U}$ of BIOTAQ polymerase (Bioline) and $2.0 \mu \mathrm{l}$ of the standardised DNA template solution (100 ng). Techne TC-512 thermocycler conditions were initially $95^{\circ} \mathrm{C}$ for $2 \mathrm{~min}$, followed by 35 cycles of $94^{\circ} \mathrm{C}$ for $30 \mathrm{~s}, 54^{\circ} \mathrm{C}$ for $1 \mathrm{~min}, 72^{\circ} \mathrm{C}$ for $90 \mathrm{~s}$, and a final elongation cycle of $72^{\circ} \mathrm{C}$ for $10 \mathrm{~min}$ (Martinez-Rodriguez et al., 2013 for details).

The amplification was checked electrophoretically in all cases: $10 \mu \mathrm{l}$ of each PCR product were run at $70 \mathrm{~V}$ in a $2 \%$ agarose gel containing $0.5 \mathrm{mg} / \mathrm{ml}$ of ethidium bromide with a track reserved for a 1-kb DNA size marker (Biotools, Madrid, Spain), before visualising using a UV transilluminator (Uvitec UVIdoc HD2, Cambridge, UK).

All PCR reactions included the appropriate controls. As positive controls for Wolbachia, Spiroplasma and eubacteria, DNA from previously characterised infected individuals of Chorthippus parallelus (Zetterstedt) (Orthoptera: Acrididae) was used (Martinez-Rodriguez et al., 2013). For the negative controls, no DNA was included in the PCR reaction mix. All amplifications were made at least twice.

\section{PCR product purification, sequencing and characterisation}

PCR-amplified sequences from the $16 \mathrm{~S} \mathrm{r} R N A$ gene of Spiroplasma and eubacteria were purified with the ExoSAP-IT kit supplied by GE Healthcare Bio-Sciences Corp. (Piscataway, NJ, USA). Resulting products were automatically sequenced by STABVIDA (http://stabvida.com/, Caparica, Portugal). The genus and taxon were assigned (when possible) with BLAST (Basic Local Alignment Search Tool) (http://blast.ncbi.nlm.nih.gov/) using the consensus sequences in the databases of the National Center for Biotechnology Information (NCBI). The new sequences as here obtained have been registered in Genbank under accession numbers KJ685895 to KJ685899.

\section{Sequence analyses, alignment and an evolutionary model}

Phylogenetic analyses were based on the available Spiroplasma sp. $16 \mathrm{~S} \mathrm{r} R N A$ nucleotide sequences. A preliminary manual analysis of the chromatograms was performed with DNAstar Lasergene Core Suite (http://www.dnastar.com) software. ClustalW software (Larkin et al., 2007) was used to align the sequences obtained and those registered from other arthropods. In all cases we found sufficient homology to enable further phylogenetic inference.

The on-line ALTER tool (Glez-Pena et al., 2010) was used to convert the data formats when they differed. Text files were manually edited with notepad++ software (http://notepad-plusplus.org/). jModeltest software (Posada, 2008) was used to select the appropriate nucleotide substitution model with the Akaike information criterion (AIC) (Akaike, 1973, 1974). The model selected was the $G T R+G+I$ variant of the General Time Reversible (GTR) model described by Tavaré (1986), which considers distinct probabilities for each base substitution on the assumption that nucleotide base frequencies may differ.

Escherichia coli was used as the outgroup to root the tree. Figtree software (http://ree.bio.ed.ac.uk/software/figtree/) was employed to visualise and edit the phylogenetic trees.

We assessed the phylogenetic reconstruction by the method of maximum likelihood (ML) (Schmidt \& von Haeseler, 2009; Vargas \& Zardoya, 2012), as described by Felsenstein (1981), using RAxML (Randomized Axelerated Maximum Likelihood) $\mathrm{v}$ 7.0.4 (Stamatakis, 2006) implementing $G T R+G+I$, as described above. Bayesian inference (BI) (Vargas \& Zardoya, 2012; Yang $\&$ Rannala, 2012) was also used for the same sequences with the MrBayes 3.2 program (Ronquist \& Huelsenbeck, 2003) simultaneously conducting two analyses by the Monte Carlo method (MCMC), each one with four Markov chains, for a minimum of $10^{6}$ generations until reaching convergence, defined as a standard deviation of split frequencies $<0.01$.

Only clades with a posterior probability $>0.95$ (Huelsenbeck \& Rannala, 2004) were considered to be statistically supported.

\section{RESULTS}

None of the 244 phasmid individuals analysed showed Wolbachia infection (see Table 1). To be certain of this negative result, positive controls (as described in the Material and Methods section) and primers for two Wolbachia

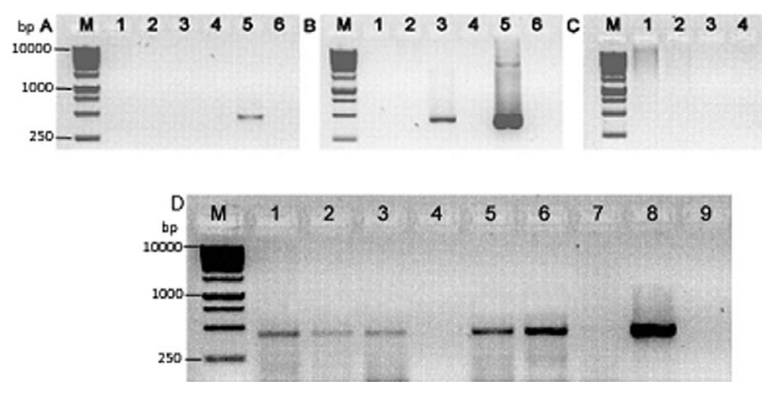

Fig. 1. Electrophoretic gels (A to D) showing the PCR amplification with primers for the $16 \mathrm{~S}$ rDNA of Spiroplasma sp. in single phasmid individuals of different stick insect species. $M$ indicates the DNA size marker. A - Tracks 1-4, Periphetes forcipatus (no infection); track 5, Ramulus artemis (positive); track 6, Phyllium jacobsoni (no infection). B - Track 1: Trachyaretaon carmelae (negative); tracks 2-5: Ramulus artemis (positive in 3 and 5), and track 6, Medauroidea extradentata (negative). C - Track 1, Phaenopharos khaoyensis (negative); tracks 2 and 3: Pharnacia ponderosa (negative); track 4, Phaenopharos khaoyensis (negative); tracks 5 and 6: positive and negative controls, respectively. D - Track 1, Diapherodes gigantea (positive); track 2, Sipyloidea sipylus (positive); track 3, Sungaya inexpectata (positive); track 4, Tirachoidea biceps (negative); track 5, Neohirasea maerens (positive); track 6, Sungaya inexpectata (positive); track 7, Phaenopharos khaoyaiensis (negative); tracks 8 and 9, positive and negative controls, respectively. 


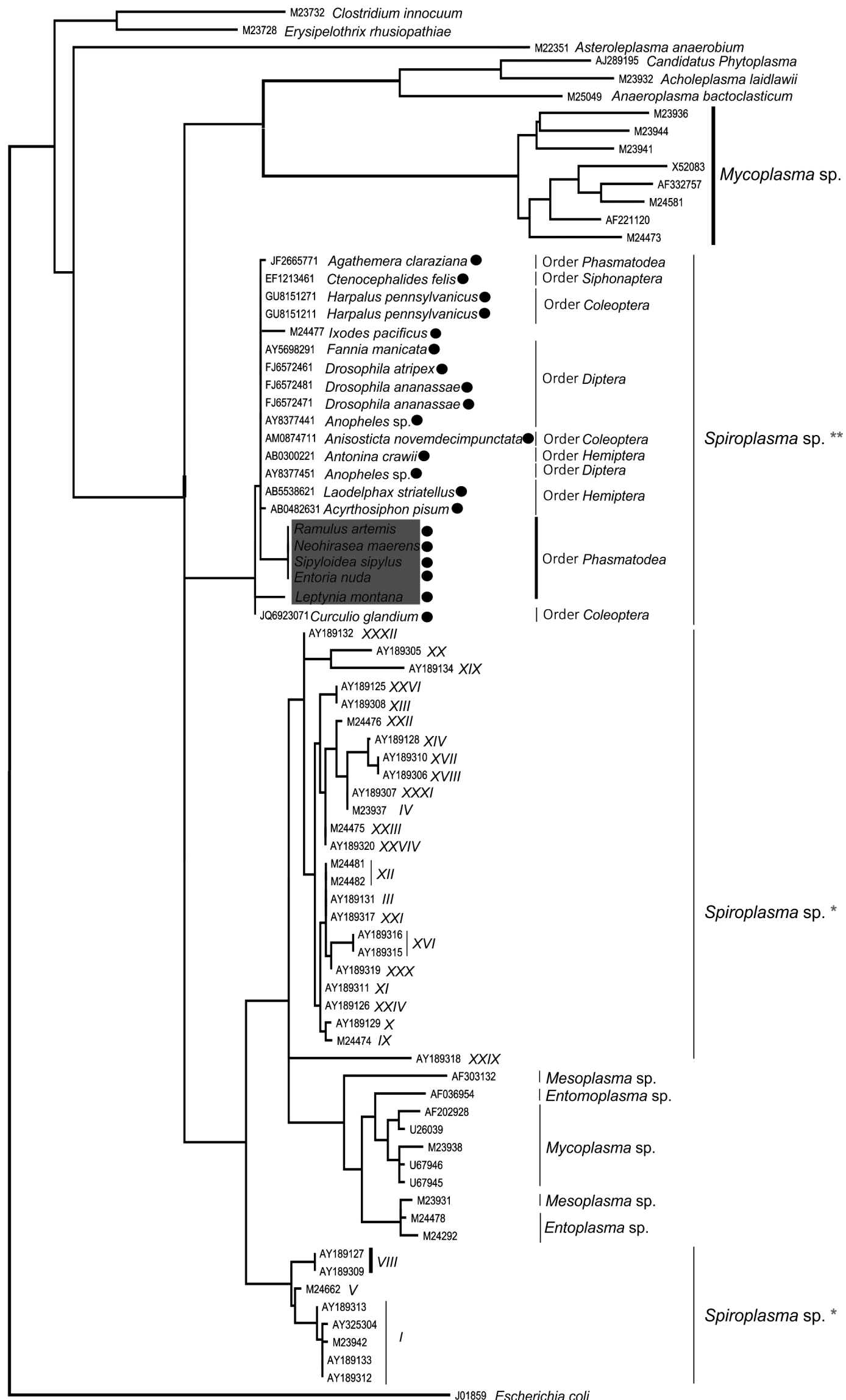

Fig. 2. Spiroplasma spp. phylogeny based on the 16S rDNA gene using the ML approach, indicating the infected host species (•). Roman numbers refer to the serological classification system for Spiroplasma. * Spiroplasma sp. belonging to previously described clades. ** Spiroplasma sp.: new clade described in this study. Phasmid species used for this study infected by Spiroplasma sp. are shaded. 


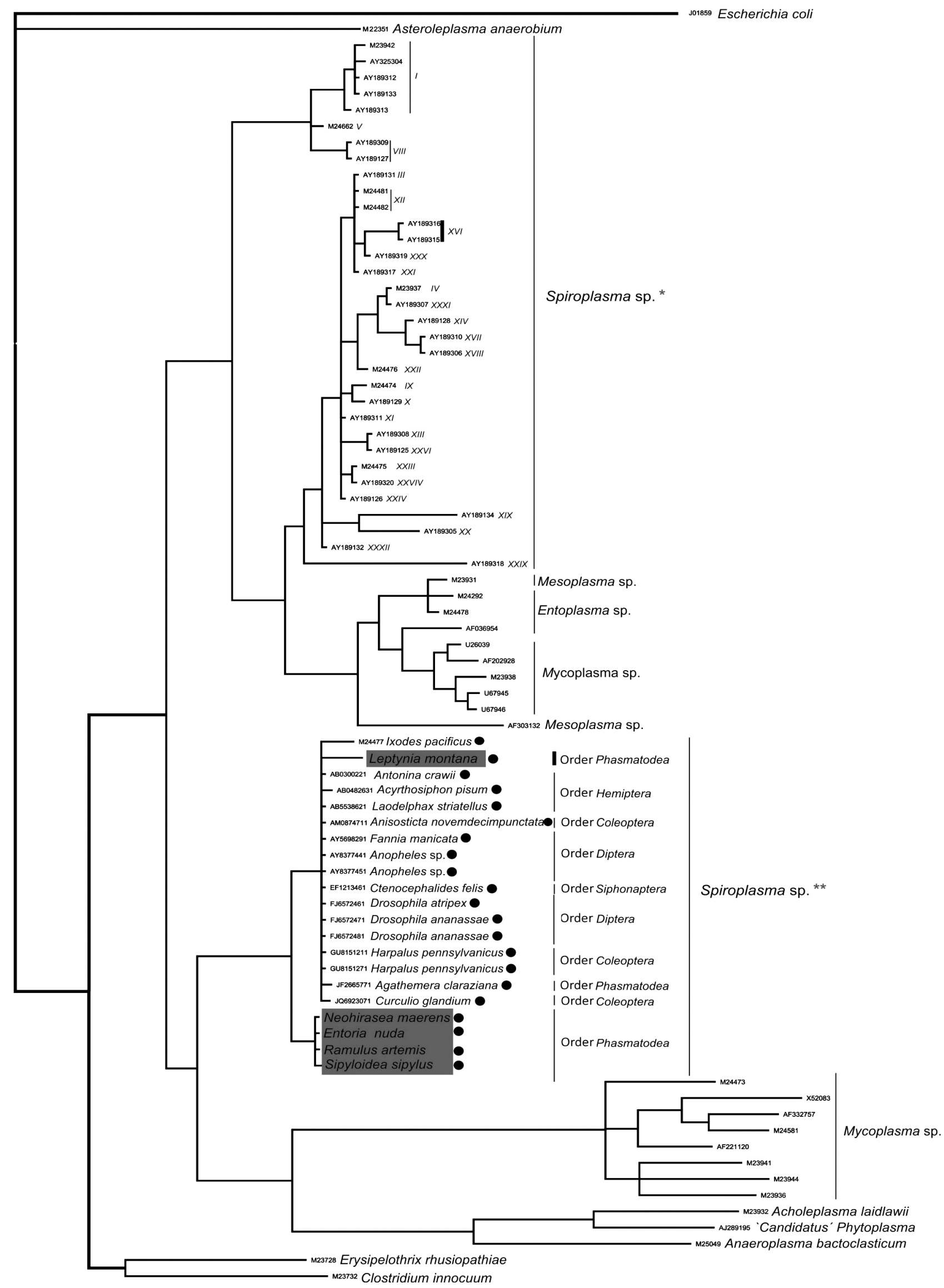

Fig. 3. Spiroplasma spp. phylogeny based on the 16S rDNA gene, using the BI approach, indicating the infected host species $(\bullet)$. Roman numbers refer to the serological classification system for Spiroplasma. * Spiroplasma sp. belonging to previously described clades. ** Spiroplasma sp.: new clade described in this study. Phasmid species used for this study infected by Spiroplasma sp. are shaded. 


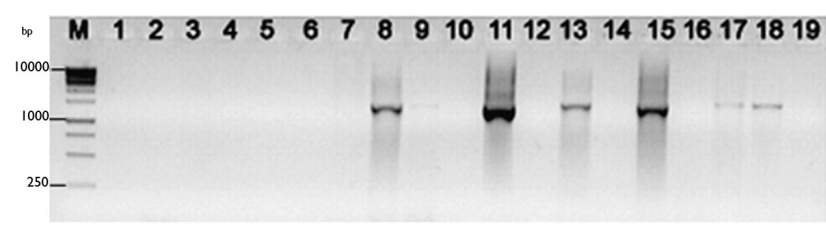

Fig. 4. Gel electrophoresis of the PCR products obtained after amplification with eubacterial universal primers for the $16 \mathrm{~S} r D N A$ gene of DNA from the phasmid species studied. Their sequencing and BLAST alignment assign them to the genus and/or bacterial species indicated below. M: DNA size marker. Tracks 1-7, Phaenopharos khaoyensis; tracks 8-9, Pharnacia ponderosa; track 10, Sungaya inexpectata; track 11, Diapherodes gigantea; track 12, Sipyloidea sipylus; track 13, Phaenopharos khaoyensis; track 14, Tirachoidea biceps; track 15, Neohirasea maerens; track 16 , Sungaya inexpectata; track 17, Phaenopharos khaoyensis, and tracks 18 and 19 correspond to the positive and negative controls, respectively. The bands in tracks 8 and 11 correspond to Serratia marcescens; track 13 to Enterobacter sp.; track 15, Serratia $\mathrm{sp}$. We were unable to determine the sequence from the bands in tracks 9 and 17 (Phaenopharos khaoyensis).

loci were used (Table 2). This enabled us to rule out false negatives, and the possibility of sequence variation in the sequences not recognized by a singular pair of primers.

Nineteen individuals belonging to the following species - Neohirasea maerens (Brunner von Wattenwyl), Ramulus artemis, Leptynia montana Scali, Entoria nuda Brunner von Wattenwyl, Sungaya inexpectata (Zompro), Diapherodes gigantea (Gmelin) and Sipyloidea sipylus (Westwood) showed PCR amplification using the primers for the Spiroplasma sp. $16 S$ rRNA gene (Fig. 1, Table 1). PCR products were automatically sequenced and sequences BLAST aligned up to the genus level. Sequences showing at least $97 \%$ of identity were considered operational taxonomic units (OTUs). 11 of the 19 analysed individuals of the strictly parthenogenetic Ramulus artemis and three of the 12 individuals of the occasionally parthenogenetic Entoria nuda proved to be infected by Spiroplasma. The other species only comprised one infected individual each (Table 1).

Phylogenetic reconstruction with these sequences based on ML and BI linked the strains detected with those previously described in phasmids (Gasparich et al., 2004; DiBlasi et al., 2011; Shelomi et al., 2013) (see * Spiroplasma sp. in Figs 2 and 3). It is of interest that our strains assign to a new and different Spiroplasma clade (** Spiroplasma sp. in Figs 2 and 3). This new clade (** Spiroplasma sp.) is further divided into two subclades (Fig. 3). One of these includes four of the phasmid species studied here: $R$. artemis, N. maerens, E. nuda and S. sipylus; the other subclade comprises various arthropods, including our L. montana and Agathemera.

The survey with universal $16 \mathrm{~S} r D N A$ PCR primers to identify other possible eubacterial endosymbionts infecting our phasmid species yielded 19 positive results. These PCR products were sequenced and BLAST-aligned. Again, using the minimum of $97 \%$ identity as the criterion for being considered an OTU, we were able to assign these sequences to different bacterial taxa (Fig. 4; Table 1).

\section{DISCUSSION}

The reproductive alterations induced by Wolbachia have been found in many organisms (Werren, 1997; Werren et al., 2008; Brucker \& Bordenstein, 2012). However, to our knowledge, the possibility that this bacterial endosymbiont infects phasmids has not previously been explored, even though these arthropods are a well-known example of occasional parthenogenesis (thelytoky) (More, 1996), a phenomenon potentially induced by this bacterium (Simon et al., 2003).

In an attempt to evaluate the role played by Wolbachia in the reproduction of these organisms, we studied the incidence of this bacterial endosymbiont in phasmid species displaying different kinds of reproductive mode - from standard bisexual reproduction, to automictic or apomictic parthenogenesis and tychoparthenogenesis. However, in none of the species and individuals analysed was the presence of Wolbachia detected by the approaches here used. This makes it very unlikely, in our opinion, that this bacterium is generally involved in the reproductive systems of phasmids, although we cannot discount the possibility of it being involved in particular cases. The absence of Wolbachia infection from all these organisms is striking, given the high proportion of insect and arthropod species infected (Zug \& Hammerstein, 2012). This by itself may be of evolutionary significance in this group of organisms.

On the other hand, we found Spiroplasma sp. in $7.7 \%$ of the individuals and $25 \%$ of the species analysed (Table 1). This bacterial endosymbiont of maternal transmission also induces reproductive alterations in several organisms. The preferential killing of male descendants is its most common effect, with a variable incidence (from 5 to $90 \%$ of infected females) depending on the taxon under consideration and other ecological and probably genetic aspects (Hurst \& Jiggins, 2000; Hutchence et al., 2012; Ventura et al., 2012; Martin et al., 2013; Sanada-Morimura et al., 2013; Harumoto et al., 2014; Xie et al., 2014).

However, we have detected this bacterium in phasmid species apparently characterised by obligate sexual reproduction, like Leptynia montana and Diapherodes gigantea, in species with obligatory parthenogenesis, such as $R a$ mulus artemis and Sipyloidea sipylus, and in Neohirasea maerens and Entoria nuda, which show occasional parthenogenesis. These preliminary results are promising and suggest the value of further research involving more individuals and populations, progeny analyses, experimental crosses between infected and uninfected individuals, and perhaps studies with previously infected individuals from parthenogenetic lineages treated with antibiotics.

A previous morphological study found Spiroplasma in the gut and certain muscle tissues of another stick insect, Agathemera spp. (Phasmatodea), but not in its eggs. This seems to rule out the possibility that this bacterium can induce the male-killing phenotype in these phasmids (DiBlasi et al., 2011). In our study, Spiroplasma was isolated from the abdomen, where the gonads (and the eggs in females) are located. This leads us to assume that the bacteria follow their standard maternal mode of transmission, the eggs 
presumably also being infected. We found the infection in both males and females, which may rule out the possibility of male killing in these cases.Even so, we are reminded of certain cases in which this phenotype only affects a limited proportion of the descendants, as observed in natural Japanese populations of Gastrolina depressa Baly (Coleoptera: Chrysomelidae): male killing is absent from northern and southern populations, but is present in 50 to $80 \%$ of the females from the centre of the islands (Chang et al., 1991; Hurst \& Jiggins, 2000).

Taxonomically, Spiroplasma is classified within the order Entomoplasmatales (Regassa \& Gasparich, 2006), in the Mollicutes lineage (Gasparich et al., 2004). Recent phylogenetic analyses based on the $16 S$ rRNA gene classified this genus as non-monophyletic (Regassa \& Gasparich, 2006). The phylogenetic characterisation of the $16 S$ rRNA sequences of the Spiroplasma detected here ascribes the strains found in $R$. artemis, $N$. maerens, $E$. nuda and $S$. sipylus to a new divergent clade, with the ML and BI approaches (Figs 2 and 3, respectively). They appear to be associated with a $16 \mathrm{~S} r R N A$ sequence previously described in a mite (GenBank: M24477), and classified in serogroup VI of Spiroplasma (Weisburg et al., 1989; Tully et al., 1995). This serogroup belongs to the Ixodetis clade, which includes the single lineage $S$. ixodetis and is at a considerable evolutionary distance from the other characterised Spiroplasma spp. (Regassa \& Gasparich, 2006). Similar divergence is also displayed by the other known case of this microorganism infecting a phasmid (DiBlasi et al., 2011; Shelomi et al., 2013). This prevents a simple interpretation of the possible biological effects of Spiroplasma in these hosts. More data from other organisms infected by these strains will shed light on this specific clade and the phenotype induced in its hosts.

Spiroplasma strains similar to $S$. ixodetis have been associated with abnormal sex ratios in the butterfly, D. chrysippus and the ladybird beetle, A. bipunctata (Regassa \& Gasparich, 2006). However, DiBlasi et al. (2011) did not find male killing induced by Spiroplasma in Agathemera spp. (Phasmatodea). In our case, we have no data that would justify the inference of a possible phenotypic effect of this bacterium in its hosts. As indicated above, further complex experiments $\left(\mathrm{F}_{1}\right.$ and $\mathrm{F}_{2}$ crosses with infected and uninfected individuals, the use of antibiotics, etc.) are needed to clarify this matter.

Given the absence of correlation between our results with Wolbachia and Spiroplasma and the reproductive mode of the stick insects analysed, we complemented our study of the microbiota of these phasmids with a broad PCR-based survey of other eubacteria, in an attempt to detect other endosymbionts that might influence their reproductive biology. Insects are usually associated with microorganisms that contribute to their physiology (Mohr \& Tebbe, 2006; Belda et al., 2011). However, our sequencing and BLAST comparison results indicate a relatively scarce microbial presence, with $\sim 8.0 \%$ (19 out of 244 ) representativeness (Fig. 4), Proteobacteria and Firmicutes being the most commonly associated phyla (Fig. 5). This low rep-

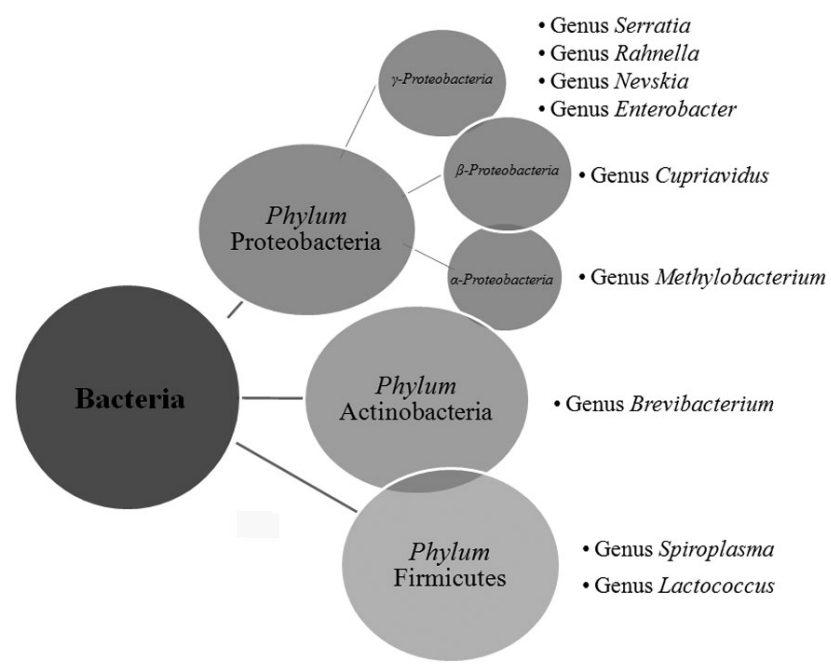

Fig. 5. The phylogeny of the bacterial endosymbionts found in Phasmatodea shows three main phyla: Proteobacteria (classes $\alpha, \beta$ and $\gamma$ ), Actinobacteria and Firmicutes. Spiroplasma spp. belongs to the latter phylum.

resentativeness may have several non-mutually exclusive explanations. Of these, we acknowledge that the captivity of the individuals studied here may have affected the bacterial diversity. In fact, this may have a significant influence in this kind of studies, as reported by Lo et al. (2006). Their non-natural diet was probably a major contributor to this, although our organisms did come from four distinct sources. Neither can we rule out the possibility that certain bacteria are insufficiently represented, which would make them difficult to detect by these methods. In any case, the bacterial taxa detected seem to be related to the nutritional function of their hosts, being microorganisms commonly associated with insects.

In summary, our results fail to reveal any definite association between bacterial infections and the reproductive modes of phasmids, more especially any clear link with the most common microorganisms involved here, Wolbachia and Spiroplasma. In the latter genus, however, further studies would ascertain its possible phenotypic or physiological effect on infected individuals and species.

ACKNOWLEDGEMENTS. We thank E. García-Barros (Universidad Autónoma de Madrid) and P.L. Mason (University of Glasgow) for their help in the experimental design and the preparation of the manuscript, respectively; P. Ruíz Mínguez, A. Fernández Ramos, J. Rodríguez García and A. Sevilla Esquinas, who kindly gave us many of the individuals used in this study, as indicated in Table 1; and F. Arroyo-Yebras for her valuable technical support. This work was supported by the Spanish MINECO $\mathrm{I}+\mathrm{D}+\mathrm{i}$ grant CGL2012-35007 with the collaboration of Chromacell S.L.

\section{REFERENCES}

AKAIKE H. 1973: Information theory as an extension of the maximum likelihood principle. In Petrov B. \& Csaki F. (eds): Second International Symposium on Information Theory. Akademiai Kiado, Budapest, pp. 267-281.

AKaiKe H. 1974: A new look at the statistical model identification. - IEEE Trans. Automat. Contr. 19: 716-772. 
Baldo L., Lo N. \& Werren J.H. 2005: Mosaic nature of the Wolbachia surface protein. - J. Bacteriol. 187: 5406-5418.

Baldo L., Dunning Hotopp J.C., Jolley K.A., Bordenstein S.R., Biber S.A., Choudhury R.R., Hayashi C., Maiden M.C., TetteLIN H. \& Werren J.H. 2006: Multilocus sequence typing system for the endosymbiont Wolbachia pipientis. - Appl. Environ. Microbiol. 72: 7098-7110.

BEDFord G.O. 1978: Biology and ecology of the Phasmatodea. Annu. Rev. Entomol. 23: 125-149.

Belda E., Pedrola L., Peretó J., Martínez-Blanch J.F., Montagud A., Navarro E., Urchueguía J., Ramón D., Moya A. \& PorCAR M. 2011: Microbial diversity in the midguts of field and lab-reared populations of the European corn borer Ostrinia nubilalis. - PLoS ONE 6: e21751.

BRUCKER R.M. \& Bordenstein S.R. 2012: Speciation by symbiosis. - Trends Ecol. Evol. 27: 443-451.

Chang K.S., Shiraishi T., Nakasuji F. \& Morimoto N. 1991: Abnormal sex ratio condition in the walnut leaf beetle, Gastrolina depressa (Coleoptera: Chrysomelidae). - Appl. Entomol. Zool. 26: 299-306.

DiBlasi E., Morse S., Mayberry J.R., Avila L.J., Morando M. \& DitTmar K. 2011: New Spiroplasma in parasitic Leptus mites and their Agathemera walking stick hosts from Argentina. - J. Invertebr. Pathol. 107: 225-228.

Duron O., Bouchon D., Boutin S., Bellamy L., Zhou L., EngelSTADTER J. \& HuRST G.D. 2008: The diversity of reproductive parasites among arthropods: Wolbachia don't walk along. BMC Biol. 6: 27

Felsenstein J. 1981: Evolutionary trees from DNA sequences: a maximum likelihood approach. - J. Mol. Evol. 17: 368-376.

Gasparich G.E., Whitcomb R.F., Dodge D., French F.E., Glass J. \& Williamson D.L. 2004: The genus Spiroplasma and its nonhelical descendants: phylogenetic classification, correlation with phenotype and roots of the Mycoplasma mycoides clade. - Int. J. Syst. Evol. Microbiol. 54: 893-918.

Glez-Pena D., Gomez-Blanco D., Reboiro-Jato M., Fdez-RivEROLA F. \& PosAdA D. 2010: ALTER: program-oriented conversion of DNA and protein alignments. - Nucl. Acids Res. 38: W14-18.

Harumoto T., Anbutsu H. \& Fukatsu T. 2014: Male-killing Spiroplasma induces sex-specific cell death via host apoptotic pathway. - PLoS Pathogens 10: e1003956.

HASELKORN T.S. 2010: The Spiroplasma heritable bacterial endosymbiont of Drosophila. - Fly 4: 80-87.

Huelsenbeck J. \& Rannala B. 2004: Frequentist properties of Bayesian posterior probabilities of phylogenetic trees under simple and complex substitution models. - Syst. Biol. 53: 904-913.

HuRst G.D. \& JigGINS F.M. 2000: Male-killing bacteria in insects: mechanisms, incidence, and implications. - Emerg. Infect. Dis. 6: 329-336.

Hurst G.D., Graf von der Schulenburg J.H., Majerus T.M., Bertrand D., Zakharov I.A., BaungaArd J., VolkL W., Stouthamer R. \& Majerus M.E. 1999a: Invasion of one insect species, Adalia bipunctata, by two different male-killing bacteria. - Insect Mol. Biol. 8: 133-139.

Hurst G.D.D., Jiggins F.M., von Der Schulenburg J.H.G., Bertrand D., West S.A., Goriacheva I.I., Zakharov I.A., Werren J.H., Stouthamer R. \& Majerus M.E.N. 1999b: Male-killing Wolbachia in two species of insect. - Proc. R. Soc. Lond. (B) 266: 735-740.

Hutchence K.J., Pade R., Swift H.L., Bennett D. \& Jiggins G.D. 2012: Phenotype and transmission efficiency of artificial and natural male-killing Spiroplasma infections in Drosophila melanogaster. - J. Invertebr. Pathol. 109: 243-247.
JigGins F.M., Hurst G.D.D., Jiggins C.D., von DER Schulenburg J.H.G \& MAJERUs M.E. 2000: The butterfly Danaus chrysippus is infected by a male-killing Spiroplasma bacterium. - Parasitology 120: 439-446.

Kremer N., Charif D., Henri H., Batallle M., Prevost G., KraAiJeVeld K. \& VaVRe F. 2009: A new case of Wolbachia dependence in the genus Asobara: evidence for parthenogenesis induction in Asobara japonica. - Heredity 103: 248-256.

LaCadena J.R. 1996: Citogenética. Editorial Complutense, Madrid, $931 \mathrm{pp}$.

LANE D.J. 1991: 16S/23S rRNA Sequencing. In Stackebrandt E. \& Goodfellow M. (eds): Nucleic Acid Techniques in Bacterial Systematics. John Wiley \& Sons, Chichester, pp. 205-248.

Larkin M.A., Blackshields G., Brown N.P., Chenna R., McGettigan P.A., McWilliam H., Valentin F., Wallace I.M., Wilm A., Lopez R., Thompson J.D., Gibson T.J. \& Higgins D.G. 2007: Clustal W and Clustal X version 2.0. - Bioinformatics 23: 2947-2948.

Lo N., Beninati T., Sassera D., Bouman E.A., Santagati S., Gern L., Sambri V., Masuzawa T., Gray J.S., Jaenson T.G., Bouattour A., Kenny M.J., Guner E.S., Kharitonenkov I.G., Bitam I. \& BANDI C. 2006: Widespread distribution and high prevalence of an alpha-proteobacterial symbiont in the tick Ixodes ricinus. — Environ. Microbiol. 8: 1280-1287.

Martin J., Chong T. \& Ferree P.M. 2013: Male killing Spiroplas$m a$ preferentially disrupts neural development in the Drosophila melanogaster embryo. — PLoS ONE 8: e79368.

Martinez-Rodriguez P., Hernandez-Perez M. \& Bella J.L. 2013: Detection of Spiroplasma and Wolbachia in the bacterial gonad community of Chorthippus parallelus. - Microb. Ecol. 66: $211-223$.

Mohr K.I. \& TeвBe C.C. 2006: Diversity and phylotype consistency of bacteria in the guts of three bee species (Apoidea) at an oilseed rape field. - Environ. Microbiol. 8: 258-272.

Montenegro H., Solferini V.N., Klaczko L.B. \& Hurst G.D. 2005: Male-killing Spiroplasma naturally infecting Drosophila melanogaster. - Insect Mol. Biol. 14: 281-287.

More E. 1996: Parthenogenesis explained. - Phasmid Stud. 5: $62-69$.

Pannebakker B.A., Pijnacker L.P., Zwahn B.J. \& Beukeboom L.W. 2004: Cytology of Wolbachia-induced parthenogenesis in Leptopilina clavipes (Hymenoptera: Figitidae). - Genome 47: 299-303.

Posada D. 2008: jModelTest: phylogenetic model averaging. Mol. Biol. Evol. 25: 1253-1256.

Rabeling C. \& Kronauer D.J. 2013: Thelytokous parthenogenesis in eusocial Hymenoptera. - Annu. Rev. Entomol. 58: 273-292.

Regassa L.B. \& Gasparich G.E. 2006: Spiroplasmas: evolutionary relationships and biodiversity. — Front. Biosci. 11: 2983 3002.

Ronquist F. \& Huelsenbeck J.P. 2003: MrBayes 3: Bayesian phylogenetic inference under mixed models. - Bioinformatics 19: $1572-1574$.

Sanada-Morimura S., Matsumura M. \& Noda H. 2013: Male killing caused by a Spiroplasma symbiont in the small brown planthopper, Laodelphax striatellus. — J. Hered. 104: 821829.

Schmidt H. \& von Haeseler A. 2009: Phylogenetic Inference Using Maximum Likelihood Methods (eds. P. Lemey, M. Salemi \& A.M. Vandamme), In The Phylogenetic Handbook: a Practical Approach to Phylogenetic Analysis and Hypothesis Testing 2nd Edition Cambridge University Press, Cambridge. pp. 181-209. 
Schwander T. \& CRespi B.J. 2009: Multiple direct transitions from sexual reproduction to apomictic parthenogenesis in Timema stick insects. - Evolution 63: 84-103.

Shelomi M., Lo W.S., Kimsey L. \& Kuo C.H. 2013: Analysis of the gut microbiota of walking sticks (Phasmatodea). $-B M C$ Res. Notes 6: 368 .

Simon C., Frati F., Beckenbach A., Crespi B.J., Liu H. \& Flook P. 1994: Evolution weighting and phylogenetics utility of mitochrondrial gene sequences and a compilation of conserved polymerase chain reactions primers. - Ann. Entomol. Soc. Am. 87: 652-701.

Simon J.C., Delmotte F., Rispe C. \& Crease T. 2003: Phylogenetic relationships between parthenogens and their sexual relatives: the possible routes to parthenogenesis in animals. Biol. J. Linn. Soc. 79: 151-163.

StAMATAKIS A. 2006: RAxML-VI-HPC: maximum likelihoodbased phylogenetic analyses with thousands of taxa and mixed models. - Bioinformatics 22: 2688-2690.

Suomalainen E., Saura A. \& LokKi J. 1987: Cytology and Evolution in Parthenogenesis. CRC Press, Boca Raton, 216 pp.

TAVARÉ S. 1986: Some probabilistic and statistical problems in the analysis of DNA sequences. - Am. Math. Soc. Lect. Math. Life Sci. 17: 57-86.

Trewick S.A., Morgan-Richards M. \& Collins L.J. 2008: Are you my mother? Phylogenetic analysis reveals orphan hybrid stick insect genus is part of a monophyletic New Zealand clade. - Mol. Phylogen. Evol. 48: 799-808.

Tully J.G., Rose D.L., Yunker C.E., Carle P., Bove J.M., WilLiAmson D.L. \& WhiтcomB R.F. 1995: Spiroplasma ixodetis sp. nov., a new species from Ixodes pacificus ticks collected in Oregon. - Int. J. Syst. Bacteriol. 45: 23-28.

Van Kuppeveld F.J., van der Logt J.T., Angulo A.F., van Zoest M.J., Quint W.G., Niesters H.G., Galama J.M. \& Melichers W.J. 1992: Genus- and species-specific identification of mycoplasmas by $16 \mathrm{~S}$ rRNA amplification. - Appl. Environ. Microbiol. 58: 2606-2615.

VARgas P. \& ZARDOYA R. 2012: El árbol de la vida-sistemática y evolución de los seres vivos. Museo Nacional de Ciencias Naturales, Madrid, 597 pp.
Ventura I.M., Martins A.B., Lyra M.L., Andrade C.A., Carvalho K.A. \& KLAcZKo L.B. 2012: Spiroplasma in Drosophila melanogaster populations: prevalence, male-killing, molecular identification, and no association with Wolbachia. - Microb. Ecol. 64: 794-801.

Watanabe M., Kageyama D. \& Miura K. 2013: Transfer of a parthenogenesis-inducing Wolbachia endosymbiont derived from Trichogramma dendrolimi into Trichogramma evanescens. J. Invertebr. Pathol. 112: 83-87.

Watts T., Haselkorn T.S., Moran N.A. \& Markow T.A. 2009: Variable incidence of Spiroplasma infections in natural populations of Drosophila species. - PLoS ONE 4: 0005703.

Weisburg W.G., Tully J.G., Rose D.L., Petzel J.P., Oyaizu H., Yang D., Mandelco L., Sechrest J., Lawrence T.G. \& van ETTEN J. 1989: A phylogenetic analysis of the mycoplasmas: basis for their classification. - J. Bacteriol. 171: 6455-6467.

WerRen J.H. 1997: Biology of Wolbachia. - Annu. Rev. Entomol. 42: 587-609.

Werren J.H., Baldo L. \& Clark M.E. 2008: Wolbachia: master manipulators of invertebrate biology. - Nature Rev. Microbiol. 6: 741-751.

Williamson D.L., Sakaguchi B., Hackett K.J., Whitcomb R.F., Tully J.G., Carle P., Bove J.M., Adams J.R., Konai M. \& HenEGAR R.B. 1999: Spiroplasma poulsonii sp. nov., a new species associated with male-lethality in Drosophila willistoni, a neotropical species of fruit fly. - Int. J. Syst. Bacteriol. 2: 611-618.

Xie J., Butler S., Sanchez G. \& Mateos M. 2014: Male killing Spiroplasma protects Drosophila melanogaster against two parasitoid wasps. - Heredity 112: 399-408.

YANG Z. \& RANNALA B. 2012: Molecular phylogenetics: principles and practice. - Nature Rev. Genet. 13: 303-314.

Zabal-Aguirre M., Arroyo F. \& Bella J.L. 2010: Distribution of Wolbachia infection in Chorthippus parallelus populations within and beyond a Pyrenean hybrid zone. - Heredity 104: 174-184.

Zug R. \& Hammerstein P. 2012: Still a host of hosts for Wolbachia: analysis of recent data suggests that $40 \%$ of terrestrial arthropod species are infected. - PLoS ONE 7: e38544.

Received November 18, 2014; revised and accepted March 27, 2015 Prepublished online May 10, 2015 